\title{
PENINGKATAN KEMAMPUAN MEMBACA RECOUNT TEXT DAN HASIL BELAJAR BAHASA INGGRIS MELALUI PENGGUNAAN MODEL PEMBELAJARAN GROUP INVESTIGATION PADA SISWA KELAS VIII.E SMP NEGERI 1 BOYOLALI
}

\author{
Bardi \\ SMP Negeri 1 Boyolali \\ bardimpd@yahoo.com
}

\begin{abstract}
The goal of this research is to increase the ability of reading Recount text and the result of studying English throughthe use of Group Investigation teaching model for the students of VIIIE State Junior High School 1 Boyolali in semester 2 year 2016/2017. This research is held for the students of VIIIE State Junior High School 1 Boyolali in semester 2 year 2016/2017. There are 26 students in this class that consists of 11 boys and 15 girls. The students are taught using Group Investigation teaching model in 2 cycles and each cycle consists of planning, acting, observing, and reflecting. In cycle I the students are taught in a big group consists of 8 students, while in cycle II the students are taught in a small group consists of 4 students. The method used in this research is Classroom Action Research (CAR). For data validation, the observation isn't done by the researcher himself but collaborate with the students and peers and also using test technique. Data analysis used in this research is descriptive comparative continued with reflection. The result of this research states that through the use of Group Investigation teaching model can increase the ability of Recount text reading and the result of studying English for the students of VIIIE State Junior High School 1 Boyolali in semester 2 year 2016/2017. From initial conditions the ability of Recount text reading low to the last conditions becomes high and the result of the studying from the initial conditions the average is 77 to the last conditions the average becomes 87 or increases 10 poin or $12.99 \%$.
\end{abstract}

Keywords: Recount text, Result of Studying, Teaching Model, Group Investigation

\begin{abstract}
Abstrak. Tujuan Penelitian ini adalah untuk meningkatkan kemampuan membacaRecount text dan hasil belajar Bahasa Inggris melaluipenggunaan model pembelajaran Group Investigation bagi siswa kelas VIIIESMP Negeri 1 Boyolali pada semester 2 tahun 2016/2017.Penelitian ini dilakukan kepada siswa kelas VIIIE SMP Negeri 1 Boyolali pada semester 2 tahun 2016/2017. Jumlah siswa dalam kelas ini adalah 26 siswa yang terdiri dari 11 siswa laki-laki dan 15 siswa perempuan. Siswa diberikan perlakuan pembelajaran dengan menggunakan model pembelajaran Group Investigation dalam 2 siklus dan setiap siklus terdiri atas perencanaan, pelaksanaan, pengamatan, dan refleksi. Siklus I pembelajaran secara kelompok besar yang terdiri atas 8 siswa, sedangkan siklus II pembelajaran secara kelompok kecil terdiri atas 4 siswa.Metode yang digunakan dalam penelitian adalah Penelitian Tindakan Kelas. Pengumpulan data melalui observasi dan studi dokumentasi. Untuk validasi data, observasi tidak dilakukan sendiri oleh peneliti, tetapi berkolaborasi dengan siswa dan teman sejawat, serta dengan teknik tes. Analisis data yang digunakan adalah deskriptif komparatif yang dilanjutkan dengan refleksi. Hasil penelitian menyatakan bahwa
\end{abstract}


melalui penggunaan model pembelajaran Group Investigation dapat meningkatkan kemampuan membaca Recount text dan hasil belajar Bahasa Inggris bagi siswa kelas VIIIE SMP Negeri 1 Boyolali pada semester 2 tahun 2016/2017. Dari kondisi awal kemampuan membaca Recount text rendah ke kondisi akhir menjadi tinggi dan hasil belajar dari kondisi awal dari rata-rata nilai 77 ke kondisi akhir rata-rata menjadi 87 naik 10 poin atau $12.99 \%$.

Kata Kunci: recount text, hasil belajar, model pembelajaran, group Investigation

\section{Pendahuluan}

Pembelajaran Bahasa Inggris mencakup 4 keterampilan berbahasa yaitu: menyimak (listening), berbicara (speaking), membaca (reading), dan membaca (writing) secara terintegrasi. Membaca adalah salah satu keterampilan berbahasa yang harus dikuasai oleh siswa untuk menangkap suatu ide atau gagasan secara tertulis. penelitian diawali dengan menggali kemampuan siswa kelas VIIIE SMP Negeri 1 Boyolali pada semester 2 tahun 2016/2017 dalam membaca Recount text dan hasil belajar Bahasa Inggris masih rendah. Hal ini dapat diketahui dari ratarata nilai ulangan harian yang masih rendah, masih di bawah Kriteria Ketuntasan Minimal (KKM) yang ditetapkan, yaitu 81 .

Kemampuan siswa dalam membaca Recount text dan hasil belajar Bahasa Inggris masih rendah, mungkin disebabkan peneliti belum memiliki kreativitas dalam memilih model pembelajaran yang tepat, sehingga siswa tidak tertarik untuk mengikuti pembe-lajaran. Pembelajaran yang disajikan belum menerapkan cooperative learning, sehinggatidak menarik bahkan menje-mukan, sehingga hasil belajar siswa rendah. Oleh karena itu perlu dicari penyebab kemampuan membaca Recount text dan hasil belajar Bahasa Inggris rendah.

Bahasa Inggris sangat penting sebagai alat komunikasi dan penguasaan teknologi, serta melihat kondisi siswa yang masih rendah dalam penguasaan kemampuan berbahasa, maka dipandang perlu untuk meningkatkan kemampuan berbahasa tersebut utamanya membaca Recount text. Dengan penelitian inidiharapkan kemampuan membaca Recount text dan hasil belajar Bahasa Inggris dapat meningkat dan rata-rata di atas Kriteria Ketuntasan Minimal (KKM), dengan melakukan kegiatan pembelajaran yang bermakna dengan menggunakan model pembelajaran yang tepat.

Selama ini telah digunakan berbagai model pembelajaran yang sesuai dengan silabus dan telah dituangkan dalam rencana pelaksanaan pembelajaran, namun demikian hasilnya belum sesuai yang diharapkan.Oleh karena itu, guru perlumengkreasikan model pembelajaran sebagai bagian dari metode mengajar (teaching method), yang sangat diperlukan dalam perbaikan pembelajaran yang akhirnya hasil belajar siswa dapat meningkat.

Berkenaan dengan hal tersebut, perlu dicari solusi tentang peningkatan kemampuan membacaRecount text dan hasil belajar Bahasa Inggris melalui penggunaan model pembelajaran Group Investigation. Penggunaanmodel pembelajaran ini dilakukan dengan dua tahapan, yaitu: penggunaan model pembelajaran Group Investigation secara kelompok besar dan kelompok kecil. Dengan menggunakan model pembelajaran Group Investigation ini, diharap-kan kemampuan membaca Recount text dan hasil belajar Bahasa Inggris bagi siswa kelas VIIIE SMP Negeri 1 Boyolali pada semester 2tahun 2016/2017dapat meningkat.

Berdasarkan latar belakang masalah di atas, dapat diidentifikasi permasalahan sebagai berikut: (1) mengapa kemampuan membaca Recount textdalam pelajaran Bahasa Inggris rendah; (2) mengapa hasil belajar Bahasa Inggris rendah; (3) apa yang menyebabkan kemampuan membaca Recount textdalam pelajaran Bahasa Inggris rendah; (4) apa yang menyebabkan hasil belajar Bahasa Inggris rendah. 
Dalam penelitian ini, dibatasi pada tiga masalah uatama, yaitu: (1) mengapa kemampuan membaca Recount text dalam pelajaran Bahasa Inggris bagisiswa kelas VIIIE SMP Negeri 1 Boyolalipada semester 2 tahun 2016/2017 rendah;(2) mengapa hasil belajar Bahasa Inggris bagisiswa kelas VIIIE SMP Negeri 1 Boyolali pada semester 2 tahun 2016/2017rendah;(3) mengapa kemampuan membacaRecount text dan hasil belajar Bahasa Inggris bagisiswa kelas VIIIE SMP Negeri 1 Boyolali pada semester 2 tahun 2016/2017 rendah.

Rumusan masalah sebagai berikut:Apakah melalui penggunaan model pembelajaranGroup Investigation dapat meningkatkan kemampuan membaca Recount textdalam pelajaran Bahasa Inggris bagi siswa kelas VIIIE SMP Negeri 1 Boyolalipada semester 2 tahun 2016/2017?; Apakah melalui penggunaan model pembelajaranGroup Investigation dapat meningkatkan hasil belajar Bahasa Inggris bagi siswa kelas VIIIE SMP Negeri 1 Boyolalipada semester 2 tahun 2016/2017?; Apakah melalui penggunaan model pembelajaranGroup Investigation dapat meningkatkan kemampuan membaca Recount textdan hasil belajar Bahasa Inggris bagi siswa kelas VIIIE SMP Negeri 1 Boyolalipada semester 2 tahun 2016/2017?

Tujuan penelitian adalah: Untuk meningkatkan kemampuan membaca Recount text dalam pelajaran Bahasa Inggris melalui penggunaan model pembelajaran Group Investigation bagi siswa kelas VIII. ESMP Negeri 1 Boyolalipada semester 2 tahun 2016/2017; Untuk meningkatkan hasil belajar Bahasa Inggris melalui penggunaan model pembelajaran Group Investigation bagi siswa kelas VIIIESMP Negeri 1 Boyolali pada semester 2 tahun 2016/2017; Untuk meningkatkan kemampuan membaca Recount text dan hasil belajar Bahasa Inggris melalui penggunaan model pembelajaranGroup Investigation bagi siswa kelas VIII.ESMP Negeri 1 Boyolalipada semester 2 tahun 2016/2017.

Kemampuan adalah kekuatan untuk melakukan sesuatu. Kemampuan seseorang untuk melakukan sesuatu pekerjaan atau tugas utamanya dalam belajar dipengaruhi oleh beberapa faktor. Faktor yang mempengaruhi kemampuan belajar yaitu: perasaan, emosi, kecer-dasan, bakat, kreativitas, dan kesehatan mental. Selain kelima hal tersebut, kemampuan belajar juga ditentukan oleh enam hal, yaitu: keaktifan, kerjasama, kreativitas, inisiatif, minat, dan motivasi belajar. Keenam hal ini sangat mempengaruhi hasil belajar siswa utamanya dalam pembelajaran Bahasa Inggris.

Keterampilan membaca menurut Byrne (1979:3) dalam Slamet (2009:106) pada hakikatnya bukan sekedar kemampuan membaca simbol-simbol grafis sehingga berbentuk kata, dan kata-kata disusun menjadi kalimat menurut peraturan tertentu, melainkan keteram-pilan membaca adalah kemampuan menuangkan buah pikiran ke dalam bahasa tulis melalui kalimat-kalimat yang dirangkai secara utuh, lengkap, dan jelas sehingga buah pikiran tersebut dapat dikomunikasikan kepada pembaca dengan berhasil. Menurut McCrimmon (1976:2) dalam Slamet (2009:96) membaca merupakan kegiatan menggali pikiran dan perasaan mengenai subjek, memilih hal-hal yang akan ditulis, menentukan cara membacakannya sehingga pembaca dapat memahaminya dengan mudah dan jelas. Sebagai bagian dari keterampilan berbahasa, membaca merupakan keterampilan yang sukar dan kompleks (Heaton, 1983:146 dalam Slamet, 2009:96). Membaca dapat didefinisikan sebagai suatu kegiatan penyampaian pesan (komunikasi) dengan menggunakan bahasa tulis sebagai alat medianya (Suparno dan M. Yunus, 2003:3) dalam Slamet, (2009:96). Mary S. Lawrence (1972:1) dalam Slamet, (2009:97) membaca adalah mengko-munikasikan apa dan bagaimana pikiran penulis.

Istilah Recount menurut Kurikulum 2004 bertujuan untuk mengu-raikan tentang suatu kejadian atau peristiwa yang terjadi pada waktu lewat, misalnya kecelakaan, laporan kegiatan, dan lain sebagainya. Recount adalah suatu jenis teks, yang sering digunakan dan disampaikan dalam jurnal, buku harian, 
surat pribadi, biografi/autobiografi, laporan perjalanan, laporan polisi, laporan olahraga, sejarah dan lain sebagainya (Depdiknas, 2005:24).

Recount text biasanya memiliki tiga unsur utama, yaitu: (1) Orientasi, menyebutkan orang atau benda yang melakukan atau yang terlibat di dalamnya, serta waktu, tempat, situasi dal lain-lain. (2) Daftar kejadian, berdasarkan urutan kejadiannya. (3) Reorientasi atau komentar pribadi, tidak selalu ada atau merangkum kejadian (Depdiknas, 2005:24-25). Fungsi sosial dari Recount text adalah menceritakan kembali kejadian atau peristiwa yang terjadi pada waktu lampau.

Hasil belajar Bahasa Inggris ditentukan tujuan pembelajaran yang ditetapkan. Dalam kurikulum 2004 dijelaskan bahwa untuk menentukan tujuan pembelajaran perlu ditetapkan standar kompetensi, kompetensi dasar, dan indikator. Penyusunan soal-soal berdasarkan indikator pencapaian belajar.

Untuk mengukur hasil belajar Bahasa Inggris dapat dilakukan dengan dua cara, yaitu dengan tes dan non tes. Tes dapat dilakukan secara lisan, tertulis dan perbuatan. Tes tertulis yang diguna-kan untuk mengetahui hasil belajar yang dapat dilakukan pada pokok bahasan tertentu, tengah semester, akhir semester, atau akhir kegiatan pembelajaran. Non tes dilakukan dengan cara pengamatan, dokumentasi dan portofolio. Portofolio ini akan sangat bermanfaat baik bagi guru maupun siswa dalam melakukan penilaian proses (Sukmara, 2005:118-119).

Model diartikan sebagai kerangka konseptual yang digunakan sebagai pedoman dalammelakukankegiatan(Sagala, 2011:175). Model mengajar menurut Joyce dan Weil (2000:13) dalam Sagala (2009:176) adalah suatu deskripsi dari lingkungan belajar yang menggambarkan perencanaan kurikulum, kursus-kursus, desain unit-unit pelajaran dan pembelajaran, perlengkapan belajar, bukubuku pelajaran, buku-buku kerja, program multimedia, dan bantuan belajar melalui program komputer. Model pembelajaran diartikan sebagai prosedur sistematis dalam mengorganisasikan pengalaman belajar untuk mencapai tujuan belajar.

Group Investigation adalah kelompok kecil untuk menuntun dan mendorong siswa dalam keterlibatan belajar. Metode ini menuntut siswa untuk memiliki kemampuan yang baik dalam berkomunikasi maupun dalam keterampilan proses kelompok (group process skills). Hasil akhir dari kelompok adalah sumbangan ide dari tiap anggota serta pembelajaran kelompok yang notabene lebih mengasah kemampuan intelektual siswa dibandin-gkan belajar secara individual. Eggen \& Kauchak (dalam Maimunah, 2005:21)mengemukakan Group Investigation adalah strategi belajar kooperatif yeng menempatkan siswa ke dalam kelompok untuk melakukan investigasi terhadap suatu topik. Metode Grup Investigation paling sedikit memiliki tiga tujuan yang saling terkait: (1) Group Investigasi membantu siswa untuk melakukan investigasi terhadap suatu topik secara sistematis dan analitik. Hal ini mempu-nyai implikasi yang positif terhadap pengembangan keterampilan penemuan dan membentu mencapai tujuan. (2) Pemahaman secara mendalam terhadap suatu topik yang dilakukan melaui investigasi. (3) Group Investigation melatih siswa untuk bekerja secara kooperatif dalam memecahkan suatu masalah.

Pada kondisi awal peneliti belum memanfaatkan model pembelajaran yang tepat dalam pembelajaran Bahasa Inggris. Agar kemampuan membacaRecount text dan hasil belajar Bahasa Inggris dapat meningkat, maka peneliti melakukan tindakan. Tindakan yang dilakukan yaitu dengan penggunaan model pembelajaran Group Investigation. Penggunaan model ini dilakukan dengan dua tahapan, yaitu secara kelompok besar dan kelompok kecil. Dengan melakukan kedua tindakan tersebut di atas: Diduga melalui penggu-naan model pembelajaran Group Inves-tigation dapat meningkatkan kemampuan membaca Recount text dalam pelajaran Bahasa Inggris bagi siswa kelas VIIIE SMP Negeri 1 Boyolalipada semester 
2 tahun 2016/2017; Diduga melalui penggunaan model pembelajaran Group Investigation dapat meningkatkan hasil belajar Bahasa Inggris bagi siswa kelas VIIIE SMP Negeri 1 Boyolalipada semester 2 tahun 2016/2017; Diduga melalui penggunaan model pembelajaran Group Investigation dapat meningkatkan kemampuan membaca Recount text dan hasil belajar Bahasa Inggris bagi siswa kelas VIII.E SMP Negeri 1 Boyolalipada semester 2 tahun 2016/2017.

Hipotesis tindakan dalam penelitian ini adalah: Melalui penggunaan model pembelajaranGroup Investigation dapat meningkatkan kemampuan membaca Recount text dalam pelajaran Bahasa Inggris bagi siswa kelas VIII.E SMP Negeri 1 Boyolali pada semester 2 tahun 2016/2017; Melalui penggunaan model pembelajaran Group Investigation dapat meningkatkan hasil belajar Bahasa Inggris bagi siswa kelas VIII.E SMP Negeri 1 Boyolali pada semester 2 tahun 2016/2017; Melalui penggunaan model pembelajaran Group Investigation dapat meningkatkan kemampuan membaca Recount text dan hasil belajar Bahasa Inggris bagi siswa kelas VIIIE SMP Negeri 1 Boyolali pada semester 2 tahun 2016/2017.

\section{Metode Penelitian}

Penelitian ini dilaksanakan selama enam bulan, yaitu mulai bulan Januari 2017 sampai dengan bulan Juni 2017 di kelas VIIIESMP Negeri 1 Boyolali pada tahun 2016/2017.

Subjek dalam penelitian ini adalah siswa kelas VIIIE SMP Negeri 1 Boyolali pada semester 2 tahun 2016/2017. Jumlah siswa dalam kelas ini adalah 26 siswa yang terdiri dari 11 siswa laki-laki dan 15 siswa perempuan.

Objek dalam penelitian ini adalah: kemampuan membaca Recount text, hasil belajar Bahasa Inggris, danmodel pembelajaran Group Investigation yang digunakan dalam pembelajaran Bahasa Inggris bagi siswa kelas VIIIE SMP Negeri 1 Boyolali pada semester 2 tahun 2016/2017.

Sumber data dalam penelitian ini adalah data tentang kemampuan membaca Recount text dan hasil belajar Bahasa Inggrispada kondisi awal,data tentang kemampuan membaca Recount text dan hasil belajar Bahasa Inggris pada siklus I, data tentang kemampuan membaca Recount text dan hasil belajar Bahasa Inggris pada siklus II.

Pengumpulan data dilakukan dengan cara teknik dokumentasi pada kondisi awal, teknik observasi dan teknik tes pada siklus I dan siklus II. Alat pengumpulan data yaitu dokumen catatan personal siswa, dokumen daftar nilai, lembar observasi, dan butir soal.

Validasi data tentang kemam-puan membaca Recount text dalam pelajaran Bahasa Inggris dengan teknik observasi yang dilakukan oleh peneliti dengan berkolabrasi dengan teman sejawat.Validasi data tentang hasil belajar Bahasa Inggris dilakukan dengan tes yang dilengkapi kisi-kisi soal, butir soal yang baik, kunci jawaban, dan pedoman penilaian.

Analisis data yang dilakukan dengan membandingkan tentang kemam-puan membaca Recount text pada kondisi awal dengan kondisi pada siklus I dan siklus II. Membandingkan nilai rata-rata hasil belajar Bahasa Inggris pada kondisi awal dengan siklus I dan siklus II. Setelah membandingkan kondisi awal dengan kondisi pada siklus I dan siklus II, maka dilanjutkan refleksi menentukan tindak lanjut.

Target yang diharapkan dalam tindakan ini adalah adanya peningkatan yang agak tinggi tentang kemampuan membaca Recount text dalam pelajaran Bahasa Inggris bagi siswa kelas VIIIE SMP Negeri 1 Boyolali pada semester 2 tahun 2016/2017 dan ada peningkatan rata-rata nilai hasil belajar Bahasa Inggris bagi siswa kelas VIIIE SMP Negeri 1 Boyolali pada semester 2 tahun 2016/2017 sebesar 5 poin.

Langkah pertama dalam melakukan tindakan yaitu menentukan metode penelitian. Langkah kedua yaitu menentukan tindakan dalam siklus. Penelitian tindakan kelas ini menggunakan dua siklus yaitu siklus I dan siklus II. Tindakan yang dilakukan ada dua macam yaitu penggunaan model pembelajaran Group Investigation dalam kelompok besar 
dan kelompok kecil. Penggunaan model pembelajaran Group Investigation dalam kelompok besar dilakukan pada siklus I, sedangkan penggunaan model pembelajaran Group Investigation dalam kelompok kecil dilakukan pada siklus II. Langkah ketiga yaitu menentukan tahapan tindakan pada setiap siklus. Setiap siklus ada empat tahapan tindakan yaitu: perencanaan (planning), tindakan (acting), pengamatan (observing), dan refleksi (reflecting).

\section{Hasil Penelitian dan Pembahasan}

\section{A. Deskripsi Kondisi Awal}

\section{Kemampuan Membaca Recount Text}

Setelah dilakukan pengamatan pada kondisi awal, diketahui bahwa kemampuan membaca Recount text dalam pelajaran Bahasa Inggris bagi siswa kelas VIIIE SMP Negeri 1 Boyolali pada semester 2 tahun 2016/2017 masih rendah. Kemam-puan siswa dalam membaca Recount text masih rendah, hal ini disebabkan karena dalam penyampaian pembe-lajaran, peneliti belum menggunakan model pembelajaran yang sesuai dengan materi yang disajikan.Pembelajaran yang disajikan oleh peneliti belum menerapkan masya-rakat belajar (cooperative learning), sehingga pembelajaran tidak menyenangkan bahkan menjemukan.

\section{Hasil Belajar Bahasa Inggris}

Data hasil belajar Bahasa Inggris diambil dari daftar nilai ulangan harian. Rata-rata nilai pada ulangan harian pertama adalah 73 dan pada ulangan harian kedua 77. Nilai ini masih di bawah Kriteria Ketuntasan Minimal yang ditetapkan yaitu 81 .

Hasil belajar Bahasa Inggris ini diperoleh dari nilai ulangan harian setelah dilakukan pembelajaran untuk Kompetensi Inti sebelumnya yang terdiri dari 4 Kompetensi Dasar. Data nilai ulangan harian pada kondisi awal dapat dilihat pada tabel di bawah.
Tabel 1. Nilai Ulangan Harian Kondisi Awal

\begin{tabular}{clcc}
\hline No & \multicolumn{1}{c}{ Uraian } & $\begin{array}{c}\text { Ulangan } \\
\text { Harian 1 }\end{array}$ & $\begin{array}{c}\text { Ulangan } \\
\text { Harian 2 }\end{array}$ \\
\hline 01 & Nilai Terendah & 60 & 65 \\
02 & Nilai Tertinggi & 90 & 90 \\
03 & Nilai Rerata & 73 & 77 \\
04 & Rentang Nilai & 30 & 25 \\
05 & Tuntas & 6 & 8 \\
06 & Belum tuntas & 20 & 18 \\
\hline
\end{tabular}

Dari tabel 1 di atas dapat diketahui bahwa antara ulangan harian 1 dengan nilai ulangan harian 2 nilai terendah ada peningkatan 5 poin, nilai tertinggi tetap, nilai rerata ada peningkatan 4 poin, rentang nilai ada penurunan 5 poin, tuntas ada pening-katan 2 poin, dan belum tuntas ada penurunan 2 poin.

\section{B. Deskripsi Hasil Siklus I}

1. Hasil Pengamatan

a) Kemampuan Membaca Recount Text

Dari hasil pengamatan pada siklus I diketahui bahwa agak banyak siswa yang aktif dalam mengikuti pembelajaran. Agak banyak siswa yang melakukan kerjasama dalam belajar. Kreativitas siswa dalam belajar agak tinggi.Agak sedikit siswa yang kurang inisiatif dalam belajar. Minat siswa dalam belajar agak tinggi. Motivasi siswa dalam belajar agak tinggi.

\section{b) Hasil Belajar Bahasa Inggris}

Hasil belajar Bahasa Inggris pada siklus I dapat diketahui setelah dilaksanakan ulangan harian pertama. Rekap nilai ulangan harian pembelajaran Bahasa Inggris pada siklus I dapat dilihat pada tabel di bawah. 
Tabel 2. Nilai Ulangan Harian Akhir Siklus I

\begin{tabular}{clc}
\hline No & \multicolumn{1}{c}{ Uraian } & $\begin{array}{c}\text { Ulangan Har- } \\
\text { ian 1 }\end{array}$ \\
\hline 01 & Nilai Terendah & 65 \\
02 & Nilai Tertinggi & 93 \\
03 & Nilai Rerata & 80 \\
04 & Rentang Nilai & 28 \\
05 & Tuntas & 17 \\
06 & Belum tuntas & 9 \\
\hline
\end{tabular}

Dari tabel 2 di atas dapat diketahui bahwa nilai hasil belajar Bahasa Inggrisbagi siswa kelas VIIIE SMP Negeri 1 Boyolali pada semester 2 tahun 2016/2017pada siklus I sebagai berikut: nilai terendah 65 , nilai tertinggi 93 , nilai rerata 80 , dan rentang nilai 28 , tuntas 17 , belum tuntas 9 .

\section{Refleksi}

\section{a) Kemampuan Membaca Recount Text}

Deskripsi kualitatif bahwa siswa yang aktif dalam mengikuti pembelajaran dari sedikit menjadi agak banyak. Siswa yang melakukan kerjasama dalam belajar dari sedikit menjadi agak banyak. Kreativitas siswa dalam belajar dari rendah menjadi agak tinggi. Inisiatif dalam belajar dari rendah menjadi agak tinggi.Minat siswa dalam belajar dari rendah menjadi agak tinggi. Motivasi siswa dalam belajar dari rendah menjadi agak tinggi. Maka dari itu untuk pelaksanaan pembelajaran pada siklus II peneliti akan berusaha meningkatkan kemampuan siswa dalam membaca Recount text.

\section{b) Hasil Belajar Bahasa Inggris}

Refleksi mengenai hasil belajar Bahasa Inggris dari kondisi awal sampai siklus I didasarkan pada hasil studi dokumentasi. Studi dokumentasi dilakukan antara daftar nilai ulangan harian pada kondisi awal dengan ulangan harian pada siklus I.
Tabel 3. Refleksi Hasil Belajar Bahasa Inggris Siklus I

\begin{tabular}{lll}
\hline No & \multicolumn{1}{c}{ Kondisi Awal } & \multicolumn{1}{c}{ Siklus I } \\
\hline 01 & Ulangan Harian & Ulangan Harian Pada \\
02 & Pada Kondisi Awal: & Siklus I: \\
03 & Nilai Terendah: 65 & Nilai Terendah: 65 \\
04 & Nilai Tertinggi: 90 & Nilai Tertinggi: 93 \\
05 & Nilai Rerata: 77 & Nilai Rerata: 80 \\
& Tuntas : 8 & Tuntas : 17 \\
& Belum tuntas: 18 & Belum tuntas: 9 \\
\hline
\end{tabular}

Deskripsi komparatif nilai terendah tetap dari 65 menjadi 65 , nilai tertinggi meningkat 3,3 persen dari 90 menjadi 93, nilai rata-rata meningkat 3,9 persen dari 77 menjadi 80, tuntas meningkat 112,5 persen dari 8 menjadi 17 , dan belum tuntas turun 50 persen dari 18 menjadi 9. Berdasarkan deskripsi komparatif tersebut, nilai terendah tetap, nilai tertinggi, rata-rata nilai, dan tuntas ada peningkatan sedangkan belum tuntas ada penurunan.

\section{Deskripsi Hasil Siklus II \\ 1. Hasil Pengamatan}

\section{a) Kemampuan Membaca Recount Text \\ Dari hasil pengamatan banyak} siswa yang aktif dalam mengikuti pembelajaran. Banyak siswa yang mela-kukan kerjasama dalam belajar. Kreati-vitas siswa dalam belajar tinggi. Sedikit siswa yang kurang inisiatif dalam belajar. Minat siswa dalam belajar tinggi. Motivasi siswa dalam belajar tinggi. Dengan demikian siswa tertarik untuk mengikuti pembelajaran Recount text.

\section{b) Hasil Belajar Bahasa Inggris}

Hasil belajar Bahasa Inggris pada siklus II dapat diketahui setelah dilaksanakan ulangan harian kedua. Untuk mengetahui hasil belajar Bahasa Inggris pada siklus II, maka peneliti melakukan studi dokumentasi pada daftar nilai ulangan harian kedua pada pembelajaran siklus II. Rekap nilai ulangan harian dapat dilihat pada tabel. 
Tabel 4. Nilai Ulangan Harian Akhir Siklus II

\begin{tabular}{clc}
\hline \multirow{2}{*}{ No } & \multicolumn{1}{c}{ Uraian } & Ulangan Harian \\
\hline 01 & Nilai Terendah & 73 \\
02 & Nilai Tertinggi & 95 \\
03 & Nilai Rerata & 87 \\
04 & Rentang Nilai & 22 \\
05 & Tuntas & 24 \\
06 & Belum tuntas & 2 \\
\hline
\end{tabular}

Dari tabel di atas dapat diketahui bahwa nilai hasil belajar Bahasa Inggris bagi siswa kelas VIIIE SMP Negeri 1 Boyolali pada semester 2 tahun 2016/2017 pada siklus II sebagai berikut: nilai terendah 73 , nilai tertinggi 95 , nilai rerata 87 , rentang nilai 22 , tuntas 24 , dan belum tuntas 2 .

\section{Refleksi}

\section{a. Kemampuan Membaca Recount Text}

Deskripsi kualitatif siswa yang Banyak siswa yang aktif dalam mengikuti pembelajaran. Banyak siswa yang melakukan kerjasama dalam belajar. Kreativitas siswa dalam belajar tinggi. Sedikit siswa yang kurang inisiatif dalam belajar. Minat siswa dalam belajar tinggi. Motivasi siswa dalam belajar tinggi. Dengan demikian ada peningkatan kemampuan siswa dalam membaca Recount text.

\section{b. Hasil Belajar Bahasa Inggris}

Refleksi mengenai hasil belajar Bahasa Inggris dapat dilihat pada tabel 5.

Deskripsi komparatif nilai terendah meningkat sebesar 12 persen dari 65 menjadi 73 , nilai tertinggi naik 2,2 persen dari 93 menjadi 95, nilai rata-rata meningkat 8,8 persen dari 80 menjadi 87, siswa tuntas meningkat 41 persen dari 17 menjadi 24, dan siswa belum tuntas turun 77,8 persen dari 9 menjadi 2. Berdasarkan deskripsi komparatif tersebut, nilai terendah, nilai tertinggi rata-rata nilai, dan siswa tuntas ada peningkatan, sedangkan siswa belum tuntas ada penurunan.

Tabel 5. Refleksi Hasil Belajar Bahasa Inggris Pada Siklus II

\begin{tabular}{lllll}
\hline No & \multicolumn{2}{c}{ Siklus I } & \multicolumn{2}{c}{ Siklus II } \\
\hline 01 & Ulangan Harian Pada & \multicolumn{2}{c}{ Ulangan Harian Pada } \\
02 & Siklus I: & & Siklus II: & \\
03 & Nilai Terendah & $: 65$ & Nilai Terendah & $: 73$ \\
04 & Nilai Tertinggi & $: 93$ & Nilai Tertinggi & $: 95$ \\
05 & Nilai Rerata & $: 80$ & Nilai Rerata & $: 87$ \\
& Tuntas & $: 17$ & Tuntas & $: 24$ \\
& Belum tuntas & $: 9$ & Belum tuntas & $: 2$ \\
\hline
\end{tabular}

\section{Hasil Tindakan}

1. Melalui penggunaan model pembelajaran Group Investigation dapat meningkatkan kemampuan membaca Recount text dalam pelajaran Bahasa Inggris bagi siswa kelas VIIIE SMP Negeri 1 Boyolali pada semester 2tahun 2016/2017. Dari kondisi awal kemampuan membaca Recount text rendah ke kondisi akhir kemampuan membaca Recount text menjadi tinggi.

2. Melalui penggunaan model pembelajaran Group Investigation dapat meningkatkan hasil belajar Bahasa Inggris bagi siswa kelas VIIIE SMP Negeri 1 Boyolali pada semester 2tahun 2016/2017. Dari kondisi awal hasil belajar Bahasa Inggris ratarata nilai 77 ke kondisi akhir rata-rata menjadi 87 atau meningkat sebesar 10 poin atau $12,99 \%$.

3. Melalui penggunaan model pembelajaran Group Investigation dapat meningkatkan kemampuan membaca Recount text dan hasil belajar Bahasa Inggris bagi siswa kelas VIIIE SMP Negeri 1 Boyolali pada semester 2tahun 2016/2017. Dari kondisi awal kemampuan membaca Recount text rendah ke kondisi akhir menjadi tinggi dan hasil belajar Bahasa Inggris dari kondisi awal rata-rata nilai 77 ke kondisi akhir rata-rata menjadi 87 atau naik 10 poin atau $12,99 \%$. 


\section{Simpulan}

Berdasarkan hasil penelitian dan pembahasan dapat disimpulkan bahwa.

1. Baik secara teoritik maupun empirik menyebutkan bahwa melalui penggunaan model pembelajaran Group Investigation dapat meningkat-kan kemampuan membaca Recount text dalam pelajaran Bahasa Inggris bagi siswa kelas VIIIE SMP Negeri 1 Boyolalipada semester 2 tahun 2016/2017.

2. Baik secara teoritik maupun empirik menyebutkan bahwa melalui penggunaan

model pembelajaran Group Investigation dapat meningkatkan hasil belajar Bahasa Inggris bagi siswa kelas VIIIE SMP Negeri 1 Boyolali pada semester 2 tahun 2016/2017.

3. Baik secara teoritik maupun empirik menyebutkan bahwa melalui penggunaan model pembelajaran Group Investigation dapat meningkatkan kemampuan membaca Recount text dan hasil belajar Bahasa Inggris bagi siswa kelas VIIIE SMP Negeri 1 Boyolali pada semester 2 tahun 2016/2017.

\section{Daftar Pustaka}

Akhaidah, Arsjad, dan Ridwan. 1991. Pembinaan Kemampuan Membaca Bahasa Indonesia. Jakarta: Erlangga.

Anderson, Mark and Kathy. 2003. Text Types in English. Malaysia: Macmillian Education Australia Pty Ltd

Arsyad, A. 2003.Media Pembelajaran. Jakarta: PT RajaGrafindo Persada.

Depdiknas. 1990. Sistem Pendidikan Nasional. Semarang: Media Wiyata.

.2004. Kurikulum 2004 Sekolah Menengah Pertama. Jakarta: Dirjen Dikdasmen.

. 2005. Standar Nasional Pendidikan. Solo: CV. Kharisma.

.2005. Materi Pelatihan Terintegrasi Bahasa Inggris Buku I. Jakarta: Dirjen Dikdasmen. 2005. Materi Pelatihan Terintegrasi Bahasa Inggris Buku II. Jakarta: Dirjen Dikdasmen. . 2006. Kurikulum Berbasis Kompetensi 2006. Jakarta: Dirjen Dikdasmen.

.2006. Standar Kompetensi Lulusan Untuk Pendidikan Dasar dan Menengah.Jakarta: Dirjen Dikdasmen.

Djumransjah, H.M . 2006. Filsafat Pendidikan. Malang: Bayumedia Publishing.

http://understandingtext.blogspot.com/2007/12/what-is-recount.html, diakses, 8 Februari 2017 jam 09.18

https://vivifebriyantiwordpress.wordpress.com/2011/05/26/ptk-group-investigation/, diakses, 10 Februari 2017

Mulyadi HP. 2010. Bimbingan Teknis Penelitian Tindakan Kelas (PTK). Semarang: LPMP Jawa Tengah.

Munadi, Y. 2008. Media Pembelajaran. Jakarta: Erlangga.

Slamet, St.Y. 2009. Dasar-dasar Keterampilan Berbahasa Indonesia. Surakarta: LPP UNS.

Sukmadinata, H.S. 2004. Landasan Psikologi Proses Pendidikan.Bandung: Remaja Rosdakarya. 